\title{
A review of the subfamily Eliminiinae (Cirripedia: Thoracica: Austrobalanidae), including a new genus, Protelminius nov., from the Oligocene of New Zealand
}

\author{
JOHN S. BUCKERIDGE ${ }^{1} \&$ WILLIAM A. NEWMAN ${ }^{2}$ \\ ${ }^{1}$ Earth and Oceanic Systems Research Group, RMIT University, Melbourne, VIC 3001, Australia. \\ E-mail: john.buckeridge@rmit.edu.au \\ ${ }^{2}$ Scripps Institution of Oceanography, University of California-San Diego, La Jolla, California, 92093-0202, United States of America
}

\begin{abstract}
The Elminiinae, comprising the four-plated taxa Elminius Leach, 1825 (one species), Austrominius Buckeridge, 1983 (six species), $†$ Matellionius Buckeridge, 1983 (one species), a new Oligocene genus, $\dagger$ Protelminius (one species), plus the six-plated Hexaminius Foster, 1982a (two species), is reviewed and current geographic distributions of its species updated. While originally restricted to southern Australia, New Zealand and southernmost South America, one species, A. modestus (Darwin, 1854), was introduced to England during World War II and is now more widely distributed in Europe. The status of four questionable species of Austrominius, currently attributed to a restricted region within South Australia, is discussed. A re-evaluation of the subfamily's morphology, triggered by recent phylogenetic studies, suggests it be removed from the lower Balanoidea and placed closest to the lower Tetraclitoidea, i.e. to a position envisaged for Elminius s.l. in Darwin (1854). The fossil record of the revised Austrobalanidae is re-evaluated in light of palaeogeography, indicating that the family may have originated during the Eocene in waters off what is now the Antarctic Peninsula.
\end{abstract}

Key words: Balanomorpha, Tetraclitoidea, Austrominius, Elminius, Hexaminius, $\dagger$ Matellionius, $\dagger$ Protelminius, Antarctic, Australia, New Zealand, South America, South Africa, Europe (introduced)

\section{Introduction}

Darwin (1854) reviewed Elminius Leach, 1825 and in doing so he proposed E. modestus (New South Wales, Tasmania and New Zealand) and E. simplex (New South Wales and Tasmania), in addition to recognizing two previously described species, E. kingii Gray, 1831 (Falkland Islands, Tierra del Fuego and Chiloe) and E. plicatus Gray, 1843 (New Zealand). Significantly, he placed Elminius phyletically lower than Tetraclita, which in turn he placed lower than Acasta and Balanus sensu lato. A number of inconsequential papers followed over the next century, leaving this small southern hemisphere genus in relative obscurity until $E$. modestus was introduced to England during World War II (Bishop, 1947) and European scientists began following its spread and interactions on the continent as well as in the United Kingdom. It took another couple of decades before Ross (1970) discovered that E. plicatus and E. simplex, as well as Tetraclita breviscutum Broch, 1922, formed a natural group, and he proposed a new tetraclitid genus, Epopella Ross, to accommodate them. Shortly thereafter, Newman and Ross (1976) noted that Balanus (Austrobalanus) imperator Darwin, 1854 was a tetraclitoid closely allied to Epopella and they proposed the Austrobalaninae to distinguish them from the porous-walled tetraclitid subfamilies.

The late Brian Foster's monograph of the Thoracica of New Zealand, long delayed in press, was virtually completed several years before the date of 1978 indicated on its cover - and even then it was not published until May 21, 1979. Therefore, while influenced by Newman et al. (1969), Ross (1970) and Newman and Ross (1971), the timing was such that Foster had yet to become aware that Newman and Ross (1976) had erected a new subfamily, the Austrobalaninae. He nonetheless not only accepted the transfer of E. plicatus 